\title{
NEUROTOXIC ESTERASE: CHARACTERIZATION OF THE SOLUBILIZED ENZYME AND THE CONDITIONS FOR ITS SOLUBILIZATION FROM CHICKEN BRAIN MICROSOMAL MEMBRANES WITH IONIC, ZWITTERIONIC, OR NONIONIC DETERGENTS
}

\author{
CINDA S. DAVIS* and RUDY J. RICHARDSON† \\ Toxicology Program, Neurotoxicology Research Laboratory, School of Public Health, The University \\ of Michigan, Ann Arbor, MI 48109-2029, U.S.A.
}

(Received 1 August 1985; accepted 11 September 1986)

\begin{abstract}
Neurotoxic esterase (NTE) is a membrane-bound protein found in highest concentration in brain and lymphocytes. The enzyme has no known physiological function, but its organophosphorylation and aging in neural tissue are thought to trigger the pathogenesis of organophosphorus-induced delayed neuropathy (OPIDN). Solubilization of NTE from microsomal membranes from hen or chick brain was studied with ten detergents encompassing ionic, zwitterionic, or nonionic types. Corrected yields of NTE solubilized over a range of [detergent]/[protein] ratios were determined by dividing the activity not sedimenting in detergent at $100,000 \mathrm{~g}$ for $60 \mathrm{~min}$ at $4^{\circ}$ by the activity in the original microsomal fraction with no detergent present. Highest corrected yields were obtained with sodium cholate (44\%), Triton X-100 (48\%), and nonyl-GPS (57\%). Partial loss of NTE activity occurred in the presence of detergent which could be prevented by the inclusion of asolectin in the solubilization preparation. NTE could not be solubilized by omitting detergent or by substituting $2 \mathrm{M} \mathrm{NaCl}$ for detergent. Mipafox pI values obtained from complete titration curves carried out on NTE solubilized in Triton X-100, sodium cholate, or sodium cholate/asolectin were indistinguishable from the value for native enzyme from brain homogenate. These results indicate that NTE exhibits the properties of an integral membrane protein with lipid dependence. The enzyme can be solubilized in good yield with a variety of detergents with retention of its characteristic differential inhibition by paraoxon and mipafox, a necessary prelude to bulk purification of the enzymatically active protein.
\end{abstract}

NTE $\ddagger$ is operationally defined as a phenyl valerate hydrolase activity that is resistant to inhibition by Paraoxon and sensitive to inhibition by mipafox [1]. As such, it may be classified as a subset of the carboxylic ester hydrolases (EC 3.1.1.1) [2].

Although there is abundant and cogent evidence that organophosphorylation and aging of NTE are required to trigger the axonal degeneration seen in OPIDN, nothing further is known about the actual process of pathogenesis or any physiological function

\footnotetext{
- Present address: Director, Women in Science, Center for Continuing Education of Women, The University of Michigan, Ann Arbor, MI 48109.

+ Send correspondence to: Dr. Rudy J. Richardson, Toxicology Program, M-7525 SPH-II, The University of Michigan, Ann Arbor, MI 48109.

₹ Abbreviations: NTE, neurotoxic esterase; OPIDN, organophosphorus-induced delayed neuropathy; Paraoxon, diethyl 4-nitrophenyiphosphate; mipafox, $N, N^{\prime}$-di2-propyl phosphorodiamidofluoridate; OP, organophosphonus compound; DFP, di-2-propyl phosphorofuoridate; Lubrol WX, (polyoxyethyleneglycol) 1 -cetyl-steryl alcohol; Triton X-100, (polyoxyethyleneglycol) $)_{10-4 t-}$ octylphenol; CHAPS, 3-(3'-cholamidopropyl) dimethylammonio-1-propane sulfonate; CHAPSO, 3-(3'-cholamidopropyl) dimethylammonio-1-(2-hydroxypropane sulfonate); hexyl-GPS, $n$-hexyl- $\beta$-D-glucopyranoside; heptylGPS, $n$-heptyl- $\beta$-D-glucopyranoside; octyl-GPS, $n$-octyl- $\beta$ D-glucopyranoside; nonyl-GPS, $n$-nonyl- $\beta$-D-glucopyranoside; and Tween 60 , (polyoxyethyleneglycol) $20^{- \text {-sorbitol }}$ monostearate.
}

that NTE may have [3-5]. It is remarkable that a specific chemical modification of a protein whose concentration in brain is on the order of 15 pmoles/ $g$ of tissue (wet wt) [6] can have an effect on neurons as drastic as destruction of the axon. Before this process can be understood, much more will have to be learned about the intrinsic properties of NTE.

Purification of NTE is an obvious prerequisite to characterizing the protein more fully. It is known that NTE is membrane-bound and that nearly $70 \%$ of the activity from a hen brain homogenate is recovered in the microsomal $\left(\mathrm{P}_{3}\right)$ fraction with a 2 -fold enrichment in specific activity [7]. In order to purify NTE, it must first be solubilized from membranes.

Initial attempts at solubilization resulted in producing a species with a considerably higher $\mathrm{pI}_{50}$ for inhibition by mipafox than exhibited by the native enzyme [8]. Other reports of the successful solubilization of enzymatically active NTE using organic solvents [9] or detergents [10-12] have appeared, but complete optimization procedures were not carried out in these studies. Because the choice of detergent and the [detergent]/[protein] ratio can influence markedly the physical form and the functionality of solubilized membrane proteins [13], this study was carried out in order to systematically evaluate a variety of detergents among the ionic, zwitterionic, and nonionic types with respect to the [detergent]/ [protein] ratio for maximum recovery of enzymatically active protein with retention of its original 
sensitivity to inhibition by mipafox. Because NTE has been best characterized in chicken brain [1], this tissue was used as the source of enzyme in our preliminary work $[14,15]$ as well as in the present study.

\section{MATERLALS AND METHODS}

Animals. Chicks (Gallus gallus domesticus), 1-14 days of age, of a White Leghorn strain (Napoleon Hatcheries, Napoleon, OH) were used for most experiments. For some experiments, adult laying hens of the same strain were used (Omega Chicks, Haslett, MI). Hen and chick NTE respond identically to neuropathogenic OPs in vivo $[16,17]$, and homogenates of hen and chick brain exhibit identical inhibitor titration curves with mipafox [18]. No significant differences were noted in mipafox titration curves of NTE activity between the two age groups in parallel solubilization experiments. Hens and chicks were housed separately in stainless steel wire cages $0.8 \times 0.8 \times 0.9 \mathrm{~m}$ with $1.27 \mathrm{~cm}$ mesh stainless steel wire floors. Both groups of birds were maintained in a temperature-controlled room with an automatic $12 \mathrm{hr}$ light/12 hr dark cycle; in addition, the ambient temperature in the chick cages was maintained at approximately $28^{\circ}$ by means of a heat lamp. Hens and chicks were maintained on diets of Purina Layena or Purina Growena poultry feed (Ralston Purina $\mathrm{Co}_{,}$, St. Lowis, MO) respectively. Feed and tap water were available ad lib. to both hens and chicks throughout the course of the experiments.

Chemicals. Phenyl valerate and mipafox were synthesized and purified as described previously [19]. Paraoxon was purchased from the Sigma Chemical Co. (St. Louis, MO) and purified as described previously [19]. Lubrol WX, Triton X-100, sodium cholate, and sodium deoxycholate also were purchased from the Sigma Chemical Co. CHAPS, CHAPSO, hexyl-GPS, heptyl-GPS, octyl-GPS, and nonyl-GPS were purchased from the Calbiochem-Behring Corp. (San Diego, CA). Asolectin (a soybean-derived phospholipid mixture whose major phospholipid component is phosphatidylcholine) was purchased from Associated Concentrates (Woodside, NY). Bovine serum albumin, fraction $V$, was from the Sigma Chemical Co. All other chemicals were of analytical reagent grade or the highest grade com* mercially available. Buffer pH values were corrected to $25^{\circ}$. All aqueous solutions were prepared in deionized-distilled water.

Preparation and solubilization of microsomes. All procedures were carried out at $0-4^{\circ}$. Microsomal $\left(\mathrm{P}_{3}\right)$ fractions were prepared from chick brain according to a previously described procedure [7]. Microsomal pellets, containing $20 \mathrm{mg}$ protein, were hand-homogenized with a Teflon-glass homogenizer in $11.0 \mathrm{ml}$ of the appropriate detergent-buffer suspension until a homogeneous dispersion was obtained. The buffer was $50 \mathrm{mM}$ Tris $/ 2.0 \mathrm{mM}$ EDTA, pH 8.0 at $25^{\circ}$, unless otherwise specified. This dispersion was still opaque. A $2.0 \mathrm{-ml}$ aliquot was saved for NTE and protein assays, and the remaining $9.0 \mathrm{ml}$ was centrifuged at $100,000 \mathrm{~g}$ for $60 \mathrm{~min}\left(\mathrm{r}_{\mathrm{av}}\right)$. The supernatant fractions (soluble NTE) were carefully pipetted off with a Pasteur pipette. The pellets were resuspended in $5.0 \mathrm{ml}$ of buffer. All fractions (microsomes with and without detergent, supernatant, and pellet) were assayed for NTE activity and protein. Recoveries for both protein and NTE activity (in the presence of detergent) were $95-100 \%$. Throughout this report, the [detergent]/[protein] ratios are understood to be expressed as [\% detergent $(w / v] /[\%$ protein $(w / v)]$.

When asolectin was included in the solubilization process, the detergent-buffer-asolectin mixture was sonicated using the Branson Sonifier Cell Disrupter 200 , using $2-\mathrm{sec}$ bursts of $40 \mathrm{~W}$ of power output until the suspension was clear. The microsomal pellets were then solubilized in this suspension as described above.

Assays. NTE was assayed by the colorimetric determination of the difference in the amount of phenol produced by hydrolytic cleavage of phenyl valerate between paired samples preincubated either in the presence of $100 \mu \mathrm{M}$ paraoxon or $100 \mu \mathrm{M}$ paraoxon plus $50 \mu \mathrm{M}$ mipafox, as previously described [19]. Protein was determined by the method of Lowry et al. [20], using bovine serum albumin, fraction $V$, as a reference standard.

Mipafox $p I_{50}$ determinations. NTE activity was titrated as described previously [21] by varying the concentration of mipafox $(0-1000 \mu \mathrm{M})$ at constant Paraoxon concentration $(100 \mu \mathrm{M})$ in the preincubation step $\left(20 \mathrm{~min}\right.$ at $\left.37^{\circ}\right)$ and then proceeding with the assay [19] for residual phenyl valerate hydrolase activity. The enzymatic activity for each mipafox concentration was expressed as a percent inhibition, taking the activity obtained with no mipafox in the preincubation step as $100 \%$. These data were then converted to probits [22] and plotted against - log [mipafox]. The probit transformation of the sigmoid titration curves produced a linear central segment and sharp breaks at the two infiection points. Linear regression was used to obtain the best straight line through the central segment of each curve. The $\mathrm{pI}_{50}$ values were computed using a Hewlett-Packard $32 \mathrm{E}$ calculator to convert the probit values at the inflection points to percentages, find the midpoint on the percentage scale, and substitute its probit value into the regression equation to obtain the corresponding value of $-\log [$ mipafox $][21,22]$.

Statistical analysis. Unless otherwise indicated, data in this report represent mean values of duplicate determinations $\pm S E(N)$, where $N$ is the number of separate experiments. The statistical significance of differences among mean values was evaluated using analysis of variance, with $P \leqslant 0.05$ being regarded as significant.

\section{RESULTS}

Requirement of the presence of detergent for solubilization. Solubilized NTE was defined in this study as NTE activity not sedimenting at $100,000 \mathrm{~g}\left(\mathrm{r}_{\mathrm{av}}\right)$ for $60 \mathrm{~min}$ at $4^{\circ}$. As Table 1 illustrates, neither simple hand-homogenization of chicken brain microsomal membranes in buffer $(50 \mathrm{mM}$ Tris $/ 2.0 \mathrm{mM}$ EDTA, $\mathrm{pH} 8.0$, at $25^{\circ}$ ) nor homogenization in the presence of high ionic strength (buffer $+2.0 \mathrm{M} \mathrm{NaCl}$ ) solubilized NTE to any extent. Addition of the nonionic detergent Triton $X-100$ to the buffer did result in solu- 
Table 1. Solubility of chicken brain microsomal membrane NTE in buffer, buffer $+2 \mathrm{M} \mathrm{NaCl}$, or buffer + Triton X-100

\begin{tabular}{|c|c|c|c|c|c|}
\hline \multirow[b]{2}{*}{ Medium } & \multicolumn{3}{|c|}{ NTE activity } & \multicolumn{2}{|c|}{$\%$ Yield } \\
\hline & $\begin{array}{l}\text { Original } \\
\text { microsomes } \\
\text { (A) }\end{array}$ & $\begin{array}{l}\text { Supernatant } \\
\text { (B) }\end{array}$ & Pellet & $\begin{array}{l}\text { Uncorrected } \\
100(B / A)\end{array}$ & $\begin{array}{c}\text { Corrected } \\
100(B / 784)\end{array}$ \\
\hline $\begin{array}{l}\text { Buffer } \\
\text { Buffer }\end{array}$ & 784 & 29.8 & 754 & 3.8 & 3.8 \\
\hline $\begin{array}{l}+2.0 \mathrm{M} \mathrm{NaCl} \\
\text { Buffer }\end{array}$ & 766 & 13.6 & 745 & 1.8 & 1.7 \\
\hline +Triton X-100 & 541 & 357 & 184 & 66.0 & 45.5 \\
\hline
\end{tabular}

Solubilization media consisted of buffer ( $50 \mathrm{mM}$ Tris $/ 2.0 \mathrm{mM}$ EDTA, pH 8.0 , at $25^{\circ}$, buffer $+2.0 \mathrm{M}$ $\mathrm{NaCl}$, or buffer + Triton X-100 ([detergent]/[protein] ratio $=0.82$ ). Solubilization of NTE activity from chicken brain microsomal membranes ( $20 \mathrm{mg}$ protein) was carried out at $0-4^{\circ}$ as described in Materials and Methods. Soluble NTE is the NTE activity not sedimenting after centrifugation at $100,000 \mathrm{~g}$ for $60 \mathrm{~min}$ at $4^{\circ}$ (supernatant activity = B). NTE activity units are nmoles $/ \mathrm{min} / 11 \mathrm{ml}$ final volume. The percent corrected yield is the soluble NTE activity (B) divided by the microsomal activity with no detergent present $(784 \mathrm{nmoles} / \mathrm{min} / 11 \mathrm{ml}$ final volume $) \times 100$; the percent uncorrected yield is the soluble NTE activity (B) divided by the original microsomal activity $(A)$ in the presence of any addition $(\mathrm{NaCl}$ or Triton $\mathrm{X}-100)$. These data represent duplicate determinations from a representative experiment: for solubilization with buffer or buffer $+2.0 \mathrm{M} \mathrm{NaCl}, \mathrm{N}=4$; for solubilization with buffer + Triton $X-100, N=20$. Specific activities of Triton $X-100$-solubilized NTE ranged between 30 and $50 \mathrm{nmoles} / \mathrm{min} / \mathrm{mg}$ protein in these experiments.

bilization of NTE, although the microsomal enzyme lost activity in the presence of detergent. When there is a loss in activity due to the presence of detergent, the percent yield of soluble enzyme from the microsomal membranes can be expressed either as a percentage of the microsomal activity in the presence of detergent (the uncorrected yield) or as a percentage of the original microsomal activity with no detergent present (the corrected yield).

Determination of the optimal [detergent] $/[$ protein] ratio and corrected yield. Typical solubilization curves for the solubilization of chicken brain microsomal NTE with Triton X-100, sodium cholate, and octyl-GPS are shown in Fig. 1. Note that in each case the percentage of solubilized NTE activity as measured as a percentage of the original microsomal NTE activity with no detergent present (the uncorrected yield) and the percentage of solubilized microsomal protein increased as the [detergent]/[protein] ratio increased. However, at the same time, the microsomal NTE starting activity, measured in the presence of increasing detergent concentration, decreased. The corrected solubilized microsomal NTE activity (as measured as a percentage of the surviving microsomal NTE activity in the presence of detergent) initially increased, but then decreased as the [detergent]/[protein] ratio increased. Therefore, a complete solubilization curve had to be done for each detergent, under any given set of solubilizing conditions (buffer/non-buffer; \pm lipid) in order to determine the optimal [detergent]/[protein] ratio that achieved maximum solubilization with minimal loss of NTE activity, i.e. the optimal corrected yield.

Comparison of detergents and solubilization media. Table 2 summarizes the results obtained from solubilization curves for chicken brain microsomal NTE for ten different detergents with the various compositions of the aqueous media indicated. The optimal percent yields (corrected and uncorrected) and optimal [detergent]/[protein] ratios are listed for the specific conditions employed in each case. In Tris/EDTA buffers, relatively good corrected yields of approximately 44 and $48 \%$ were obtained with sodium cholate, an ionic detergent, and Triton $X$ 100 , a nonionic detergent, respectively, but yields were rather poorer with sodium deoxycholate (ionic), Lubrol WX (nonionic), and worst of all with octyl-GPS (nonionic).

When solubilization was carried out in deionizeddistilled water instead of buffer, the corrected yield obtained with octyl-GPS improved to $39 \%$. Relatively low corrected yields were obtained with hexylGPS and the zwitterionic detergent CHAPSO, whereas the results with heptyl-GPS and CHAPS were intermediate under these conditions, comparable to the result with Lubrol WX in Tris/EDTA buffer. The high corrected yield of $57 \%$ obtained with nonyl-GPS in water cannot be ascribed with statistical significance because it was obtained from a single experiment. However, the result is thought to be reliable due to the fact that it was derived from a complete solubilization curve and because relatively low variances were found in the yields obtained with Triton X-100 and sodium cholate, where multiple curves were done. For anticipated future work on the purification of NTE, it was considered an advantage to keep the enzyme in a medium of similar ionic composition and $\mathrm{pH}$ to that used for its assay. Therefore, since acceptably high yields were obtained in Tris/EDTA buffer with sodium cholate and Triton X-100, these detergents were selected for further characterization of NTE solubilization and solubilized NTE.

Effect of lipid. The addition of lipid to the assay mixture in the form of sonicated asolectin did not restore significantly microsomal NTE activity lost during solubilization with sodium cholate, but if the asolectin was suspended in the detergent-buffer mixture and thus included in the solubilization process, loss of microsomal NTE activity was prevented (Fig. 

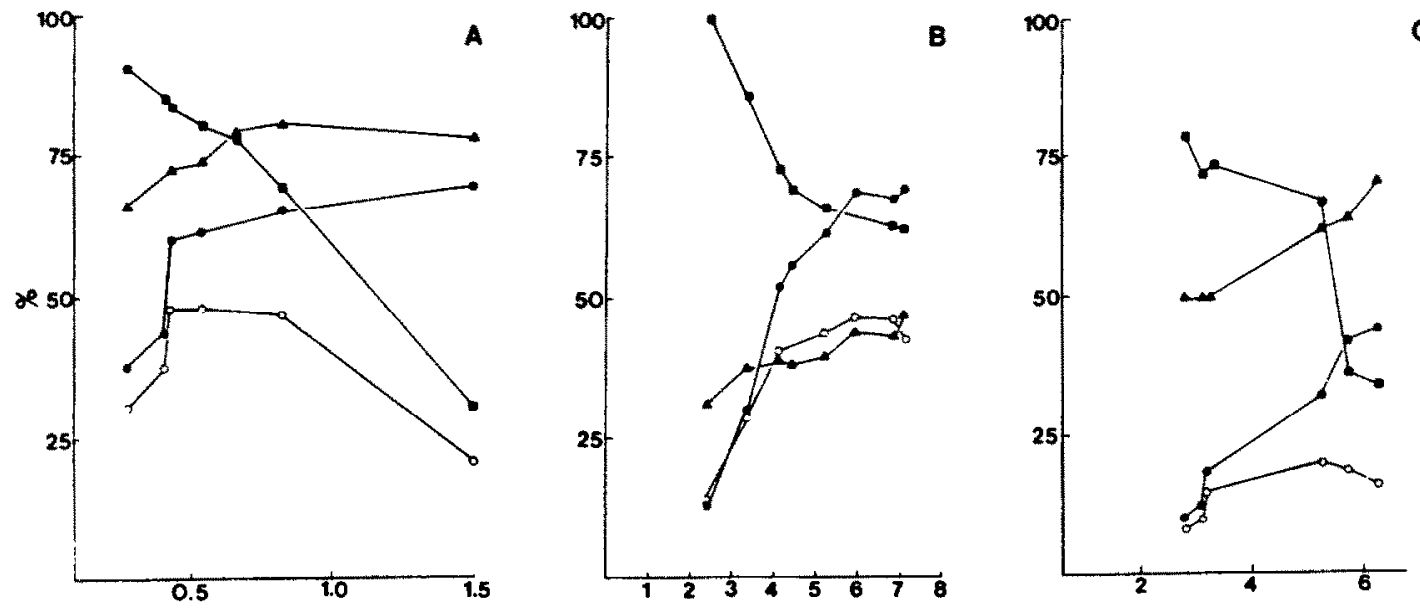

\% Detergent / \% Protein

Fig. 1. Typical solubilization curves for (A) Triton X-100, (B) sodium cholate, and (C) octyl-GPS Solubilizing buffer was $10 \mathrm{mM}$ Tris $/ 0.40 \mathrm{mM}$ EDTA, pH 8.0 (at $25^{\circ}$ ) for Triton X-100 and $50 \mathrm{mM}$ Tris/ $2.0 \mathrm{mM}$ EDTA, $\mathrm{pH} 8.0$ (at $25^{\circ}$ ) for sodium cholate and octyl-GPS. Chicken brain microsomal membranes were homogenized in the appropriate detergent-buffer suspensions at $0-4^{\circ}$ over a range of [detergent]/ [protein] ratios and centrifuged at $100,000 \mathrm{~g}\left(\mathrm{r}_{\mathrm{sv}}\right)$ for $60 \mathrm{~min}$ to obtain a supernatant fraction (soluble NTE) and pellet; all fractions (microsomes with and without detergent, supernatant, and pellet) were assayed for NTE activity and protein as described in Materials and Methods; recoveries for both were 95-100\%. Each point represents a duplicate determination from a single experiment: (E) percent microsomal NTE activity in detergent-microsome mixture; $(\boldsymbol{A})$ percent microsomal protein solubilized; (O) percent NTE activity solubilized using detergent-microsome NTE activity as control (uncorrected yield); and (O) percent NTE activity solubilized using microsomal NTE activity with no detergent present as control (corrected yield).

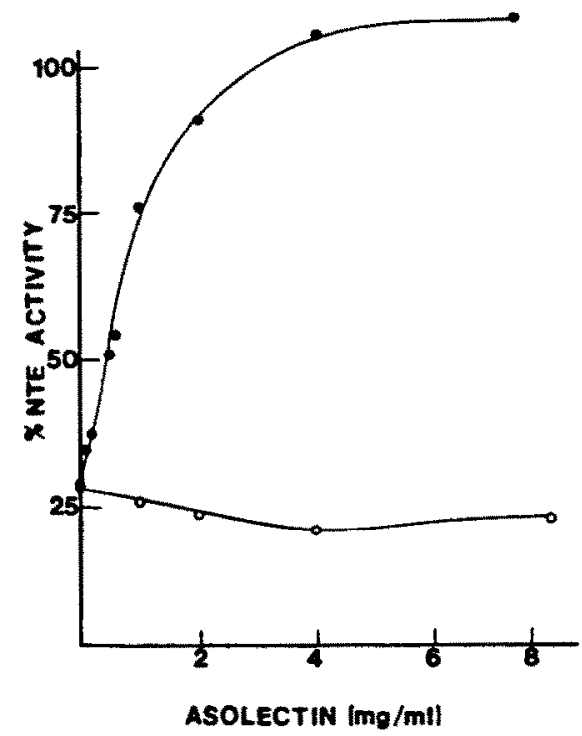

Fig. 2. Effect of asolectin on NTE activity of chicken brain microsomal membranes suspended in sodium cholate. Key: (O) asolectin added to NTE assay mixture following sus. pension of microsomes in detergent; and (O) asolectin included with detergent during suspension of microsomes. Medium was $50 \mathrm{mM}$ Tris $/ 2.0 \mathrm{mM}$ EDTA, $\mathrm{pH} 8.0$, with a final sodium cholate concentration of $2.0 \%(w / v)$ and a [detergent]/[protein] ratio of 6.1. Preparation of suspensions and conditions for NTE assay are described in Materials and Methods.
2). The corrected yield of sodium cholate-solubilized NTE activity also increased in the presence of asolectin, although the amount of protein solubilized remained the same (Table 3).

Characterization of solubilized NTE by mipafox inhibition. NTE was solubilized with Triton X-100, sodium cholate, or sodium cholate plus asolectin. The optimal [detergent]/[protein] ratios and Tris/ EDTA buffer compositions given in Table 2 were used; the final concentration of asolectin was $4.0 \mathrm{mg}$ / ml. Mipafox titration curves for these preparations are shown in Fig. 3. The $\mathrm{pI}_{50}$ values for NTE solubilized in Triton X-100, sodium cholate, or sodium cholate plus asolectin were $5.13 \pm 0.03(\mathrm{~N}=3)$, $5.18 \pm 0.06 \quad(\mathrm{~N}=3)$, and $5.09 \pm 0.09 \quad(\mathrm{~N}=3)$ respectively. These values are statistically indistinguishable from each other, as well as from the previously determined value of $5.10 \pm 0.26(\mathrm{~N}=3)$ for membrane-bound NTE from hen brain homogenate [21].

To determine whether the solubilization process might be either unmasking NTE activity that was cryptic to assay in its membrane-bound state, or creating phenyl valerate-hydrolyzing activity with NTE-like inhibitor characteristics, aliquots of chicken brain microsomal membranes were preincubated with buffer, $10 \mu \mathrm{M}$ mipafox, or $100 \mu \mathrm{M}$ mipafox for $20 \mathrm{~min}$ at $37^{\circ}$. The membranes were then solubilized in the usual manner using Triton X-100 with a [detergent]/[protein] ratio of 0.64 . Each sol- 
Table 2. Optimal solubilization characteristics of various detergents in Tris/EDTA buffers or deionized-distilled water for obtaining enzymatically active NTE from chicken brain microsomal membranes

\begin{tabular}{|c|c|c|c|c|}
\hline Detergent & Medium & $\begin{array}{c}\text { Optimum } \\
\text { [detergent] } / \text { [protein] } \\
\text { ratio }\end{array}$ & $\begin{array}{c}\% \text { Yieid } \\
\text { (uncorrected) }\end{array}$ & $\begin{array}{l}\% \text { Yield } \\
\text { (corrected) }\end{array}$ \\
\hline $\begin{array}{l}\text { Sodium cholate } \\
\text { (ionic) }\end{array}$ & $\begin{array}{l}50 \mathrm{mM} \text { Tris/ } \\
2.0 \mathrm{mM} \text { EDTA, } \\
\text { pH } 8.0\end{array}$ & $6.1 \pm 0.60(10)$ & $66.0 \pm 4.7(10)$ & $43.9 \pm 1.3(10)$ \\
\hline $\begin{array}{l}\text { Sodium } \\
\text { deoxycholate } \\
\text { (ionic) }\end{array}$ & $\begin{array}{l}10 \mathrm{mM} \text { Tris/ } \\
0.40 \mathrm{mM} \text { EDTA, } \\
\text { pH } 8.0\end{array}$ & 0.83 & 38 & 23 \\
\hline $\begin{array}{l}\text { CHAPS } \\
\text { (2witterionic) }\end{array}$ & $\mathrm{H}_{2} \mathrm{O}$ & 2.5 & 35 & 28 \\
\hline $\begin{array}{l}\text { CHAPSO } \\
\text { (zwitterionic) }\end{array}$ & $\mathrm{H}_{2} \mathrm{O}$ & 4.9 & 43 & 16 \\
\hline $\begin{array}{c}\text { Triton } X \cdot 100 \\
\text { (nonionic) }\end{array}$ & $\begin{array}{l}10 \mathrm{mM} \text { Tris/ } \\
0.40 \mathrm{mM} \text { EDTA, } \\
\text { pH } 8.0\end{array}$ & $0.63 \pm 0.13(19)$ & $63.7 \pm 2.17(9)$ & $47.7 \pm 0.50(9)$ \\
\hline $\begin{array}{l}\text { Lubrol WX } \\
\text { (nonionic) }\end{array}$ & $\begin{array}{l}10 \mathrm{mM} \text { Tris/ } \\
0.40 \mathrm{mM} \text { EDTA, } \\
\text { pH } 8.0\end{array}$ & 0.62 & 36 & 29 \\
\hline $\begin{array}{l}\text { Hexyl-GPS } \\
\text { (nonionic) }\end{array}$ & $\mathrm{H}_{2} \mathrm{O}$ & 4.3 & 11 & 17 \\
\hline $\begin{array}{l}\text { Heptyl-GPS } \\
\text { (nonionic) }\end{array}$ & $\mathrm{H}_{2} \mathrm{O}$ & 4.8 & 27 & 30 \\
\hline $\begin{array}{l}\text { Octyl-GPS } \\
\text { (nonionic) }\end{array}$ & $\mathrm{H}_{2} \mathrm{O}$ & 5.1 & 44 & 39 \\
\hline $\begin{array}{l}\text { Octyl-GPS } \\
\text { (nonionic) }\end{array}$ & $\begin{array}{l}50 \mathrm{mM} \text { Tris/ } \\
2.0 \mathrm{mM} \text { EDTA, } \\
\text { pH } 8.0\end{array}$ & 5.3 & 31 & 19 \\
\hline $\begin{array}{l}\text { Nonyl-GPS } \\
\text { (nonionic) }\end{array}$ & $\mathrm{H}_{2} \mathrm{O}$ & 5.6 & 71 & 57 \\
\hline
\end{tabular}

Membranes were solubilized in the various media at $0-4^{\circ}$, and NTE and protein were assayed in the original membranes and in the supernatant and pellet after centrifugation of the solubilization mixture at $100,000 \mathrm{~g}$ for 60 min at $4^{\circ}$ as described in Materials and Methods. The optimal [detergent]/[protein] ratios were determined from solubilization curves, as shown in Fig. 1, and correspond to the highest percent yield obtained in each case. The percent corrected yield is the ratio of NTE activity in the soluble fraction divided by the NTE activity in the original microsomal fraction without detergent present $\times 100$; the percent uncorrected yield is the soluble NTE activity divided by the original microsomal NTE activity in the presence of detergent $\times 100$. Values determined for Triton X-100 and sodium cholate represent the mean $\pm S E$ for nine and ten experiments respectively; values for other detergents represent optima from single sets of solubilization curves.

Table 3. Effect of asolectin on the solubilization of NTE from chicken brain microsomal membranes with sodium cholate in Tris/EDTA buffer

\begin{tabular}{lcccc}
\hline & $\begin{array}{c}\text { Microsomal } \\
\text { NTE } \\
\text { activity }\end{array}$ & $\begin{array}{c}\text { Soluble } \\
\text { NTE } \\
\text { activity }\end{array}$ & $\begin{array}{c}\text { \% NTE } \\
\text { solubilized } \\
\text { (corrected } \\
\text { yield) }\end{array}$ & $\begin{array}{c}\text { Protein } \\
\text { solubilized } \\
\text { (mg) }\end{array}$ \\
\hline $\begin{array}{l}\text { Buffer } \\
\text { Buffer } / 2 \%(w / v) \text { cholate }\end{array}$ & 789 & 131 & 16.6 & 10.5 \\
$\begin{array}{l}\text { Buffer } / 2 \%(w / v) \text { cholate/ } \\
\quad 0.2 \mathrm{mg} / \mathrm{ml} \text { asolectin }\end{array}$ & 225 & 167 & 21.2 & 9.5 \\
$\begin{array}{c}\text { Buffer } / 2 \%(w / v) \text { cholate/ } \\
2.0 \mathrm{mg} / \mathrm{ml} \text { asolectin }\end{array}$ & 343 & 474 & 60.1 & 10.5 \\
\hline
\end{tabular}

Membrane aliquots ( $20 \mathrm{mg}$ protein) were solubilized as described in Materials and Methods in media consisting of buffer ( $50 \mathrm{mM}$ Tris $/ 2.0 \mathrm{mM}$ EDTA, $\mathrm{pH} 8.0$ ), buffer + sodium cholate $(2.0 \%(w / v)$ final concentration $)$, or buffer $/$ sodium cholate + asolectin $(0.20$ or $2.0 \mathrm{mg} / \mathrm{ml}$ final concentration). The [detergent]// protein] ratio was 6.1 . Soluble NTE activity is activity not sedimentable by centrifugation at $100,000 \mathrm{~g}$ for $60 \mathrm{~min}$ at $4^{\circ}$. Data are mean values from two experiments; corresponding individual values were within $10 \%$ of each other. NTE activity is expressed as nmoles $/ \mathrm{min} / 11 \mathrm{ml}$ final volume. The percent corrected yield is the soluble NTE activity divided by the original microsomal activity with no detergent present $\times 100$. 

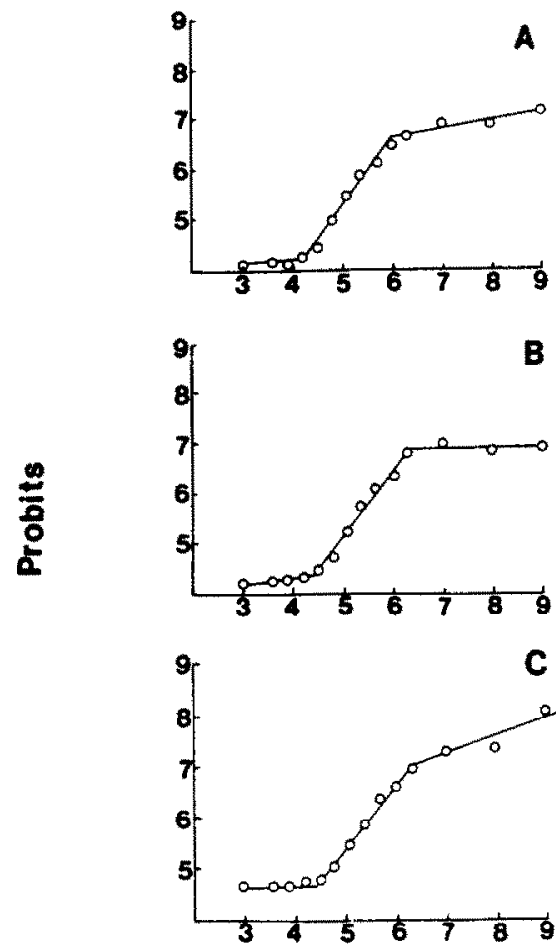

- $\log$ (Mipatox]

Fig. 3. Probit-transformed plots of mipafox titration of residual phenyl valerate hydrolase activity, in the presence of $100 \mu \mathrm{M}$ Paraoxon, of chicken brain microsomal mem. branes solubilized in: (A) Triton $X-100 / 10 \mathrm{mM}$ Tris/ $0.40 \mathrm{mM}$ EDTA, pH 8.0, [detergent] $/[$ protein] $=0.64 ;(B)$ sodium cholate $/ 50 \mathrm{mM}$ Tris $/ 2.0 \mathrm{mM}$ EDTA, pH 8.0 , [detergent $] /[$ protein] $=6.4$; and (C) sodium cholate/ $50 \mathrm{mM}$ Tris $2.0 \mathrm{mM}$ EDTA, pH $8.0 / 4.0 \mathrm{mg} / \mathrm{ml}$ asolectin, [detergent]/[protein] $=6.4$ as described in Materials and Methods. Each plot is a composite of plots obtained from duplicate determinations in three separate experiments. The mipafox $\mathrm{pl}_{50}$ values were $5.13 \pm 0.03,5.18 \pm 0.06$, and $5.09 \pm 0.09$ for the preparations solubilized in Triton X100 , sodium cholate, and sodium cholate/asolectin respectively.

uble fraction was then titrated (additional preincubation for $20 \mathrm{~min}$ at $37^{\circ}$ ) with increasing mipafox concentrations $(0-1000 \mu \mathrm{M})$ at a constant Paraoxon concentration $(100 \mu \mathrm{M})$. The residual phenyl valerate esterase activity was then determined to yield the three curves shown in Fig. 4. The maximum activity obtained from the preparation that was preincubated in buffer alone was arbitrarily set to $100 \%$. The relative amounts of NTE were calculated to be 85.5 , 31.2 , and $0.0 \%$ for the preparations preincubated with buffer, $10 \mu \mathrm{M}$ mipafox, and $100 \mu \mathrm{M}$ mipafox respectively. Using the relationship, $\ln \left(v / v_{0}\right)=$ $-k_{i}[I] t$, for the progressive inhibition of an esterase by an $\mathrm{OP}$, where $v_{0}$ and $v$ are the rates or activities before and after preincubation with inhibitor respectively; $k_{i}$ is the bimolecular rate constant of inhibition; [I] is the inhibitor concentration during the preincubation; and $t$ is the time of preincubation [23]; it is possible to derive the expression, $\ln \left(v / v_{0}=\right.$

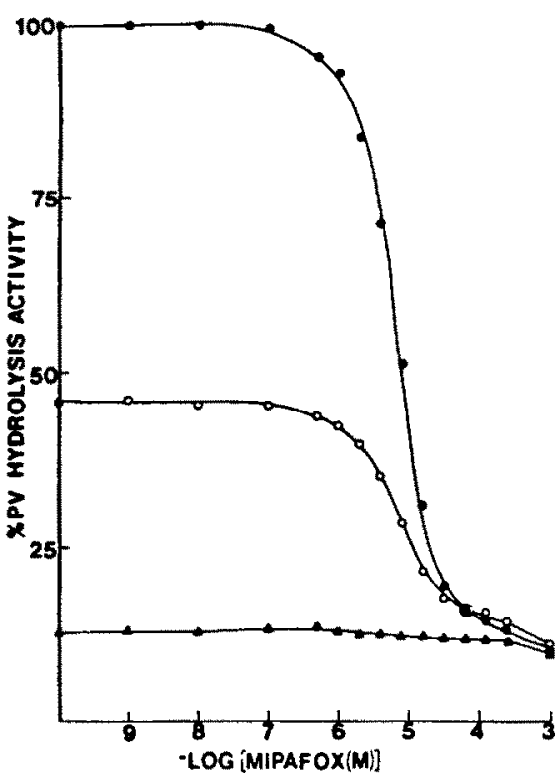

Fig. 4. Mipafix titration of residual phenyl valerate hydrolase activity solubilized from chicken brain microsomal membranes preincubated with $100 \mu \mathrm{M}$ Paraoxon and $0(0)$, $10(\mathrm{O})$, or $100 \mu \mathrm{M}$ (A) mipafox. Microsomes were preincubated with inhibitors for $20 \mathrm{~min}$ at $37^{\circ}$ and then solubilized in $10 \mathrm{mM}$ Tris $/ 2.0 \mathrm{mM}$ EDTA, pH 8.0 , using Triton $\mathrm{X}-100$ at a [detergent]/[protein] ratio of 0.64 ; residual phenyl valerate hydrolase activity in the soluble fraction was determined after a further 20 -min incubation with $100 \mu \mathrm{M}$ Paraoxon and $0-1000 \mu \mathrm{M}$ mipafox. Each point represents a duplicate determination.

$-0.693[\mathrm{I}] /\left[\mathrm{I}_{50}\right]$, which allows calculation of the rate or activity ratio at a concentration of inhibitor [I] if the $\left[I_{50}\right]$ is known. Substituting the experimentally determined $I_{50}$ value for NTE solubilized in Triton $\mathrm{X}-100$, the theoretical values for the fraction of the maximum NTE activity remaining after preincubation with 10 or $100 \mu \mathrm{M}$ mipafox are 0.392 and 0.0001 respectively. This is in excellent agreement with the respective observed ratios of $31.2 / 85.5=$ 0.365 and $0.0 / 85.5=0.0$. Moreover, the $\mathrm{pI}_{50}$ for each curve was determined to be 5.10 , which is in the range of values determined for native NTE from brain homogenate [21] and NTE solubilized from microsomal membranes with Triton $\mathrm{X}-100$ without prior preincubation with buffer or inhibitors $[14,15]$.

\section{Discussion}

This study extends the usefulness of earlier work on the solubilization of NTE [10-12] by providing optimum [detergent]/[protein] ratios and corrected yields of solubilized enzymatically active protein for a variety of detergents. The highest corrected yields of solubilized NTE were obtained in this study with sodium cholate, Triton X-100, and nonyl-GPS; there are advantages and disadvantages associated with each of these detergents.

The ionic detergent sodium cholate has a greater tendency than the nonionic detergents Triton X-100 and nonyl-GPS to disrupt protein-protein interactions with concomitant dissociation of quaternary 
structure that may be present in component subunits [13]. The enzymological characteristics of the individual catalytic subunits may be preserved, but the large-scale physical properties of the native structure may be lost.

Even though membrane proteins generally require detergent to be present during purification to prevent precipitation of the protein from solution, removal of detergent is ultimately required in order to obtain the isolated protein $[13,24]$. Removal of detergents is also required in membrane reconstitution experiments, in which detergents are exchanged for lipid [25]. The critical micelle concentration of Triton X100 is $0.3 \mathrm{mM}[13,26]$, which is significantly less than that of either sodium cholate $(8-10 \mathrm{mM}$ in media of low ionic strength) $[13,26]$ or nonyl-GPS $(6.5 \mathrm{mM})$ [27]. The relatively low critical micelle concentration of Triton X-100 renders it much more difficult to remove by simple dialysis than the other two detergents, although resins are available that allow its removal by selective absorption $[25,28]$.

Evidence of the native functionality of NTE in our soluble preparations was provided by showing that the mipafox pI $_{50}$ for the Paraoxon-resistant activity in the soluble fraction was unchanged from that obtained for membrane-bound enzyme. Moreover, mipafox titrations of activity solubilized from membranes that had already been preincubated with Paraoxon and increasing concentrations of mipafox indicated that no activity was being released that was cryptic to assay in the native state, nor was there activity released during solubilization that could be mistaken for NTE.

Finally, the results of this study suggest that NTE may be an integral membrane protein. Such proteins have been characterized as requiring detergent for solubilization, losing activity upon solubilization, and generally associated with or requiring lipid for maximal activity $[26,29]$. Thus, NTE was not appreciably solubilized by homogenization in buffer or in buffer supplemented with a high salt concentration, whereas detergents were effective solubilizing agents, with their degree of effectiveness dependent upon the type of detergent, the [detergent]/[protein] ratio, and the presence or absence of buffer salts in the medium. Detergents caused a loss of NTE activity in the microsomal starting material. This observation, coupled with the results of the experiments with asolectin, is reminiscent of what has been observed in the solubilization of other membranebound proteins. For example, with the tetrodotoxinbinding protein of electric organ membrane [30] and the $\mathrm{Na}^{+} / \mathrm{K}^{+}$-ATPase (EC 3.6.1.37) of electric eel [31], inclusion of lipid in the solubilization medium prevents the loss of binding properties or enzymatic activity otherwise incurred during solubilization. A number of membrane-bound enzymes require lipid for activity, although the exact nature of this lipid dependency often remains uncertain [29]. Our results indicate that NTE exhibits at least some degree of lipid dependence. However, it will require further enzyme purification and experimentation with highly purified lipid preparations to determine whether NTE requires a specific cofactor-like lipid for maximal activity or if it simply demonstrates a more generalized lipid dependency.
Acknowledgements-This work was supported, in part, by NIH research grants ES 01611 and ES 02770; EPA research grant 805339; and by a research grant and postdoctoral fellowship (to C.S.D.) from the Monsanto Fund.

\section{REFERENCES}

1. M. K. Johnson, Rev. biochem. Toxic. 4, 141 (1982).

2. J. M. Chemnitius and R. Zech, Molec. Pharmac. 23, 717 (1983)

3. M. K. Johnson, J. Neurochem. 23, 785 (1974).

4. C. S. Davis and R. J. Richardson, in Experimental and Clinical Neurotoxicology (Eds. P. S. Spencer and H. H. Schaumburg), p. 527. Williams \& Wilkins, Baltimore (1980).

5. R. J. Richardson, in Cellular and Molecular Neurotoxicology (Ed. T. Narahashi), p. 285. Raven Press, New York (1984).

6. D. G. Williams, Biochem. J. 209, 817 (1983).

7. R. J. Richardson, C. S. Davis and M. K. Johnson, J. Neurochem. 32, 607 (1979).

8. M. K. Johnson, Biochem. J. 122, 51 (1971).

9. B. W. Schwab, C-S. G. Davis, P. H. Miller and R. J. Richardson, Biochem. biophys. Res. Commun. 132, 81 (1985).

10. Y. Ishikawa, E. Chow, M. G. McNamee, M. McChesney and B. W. Wilson, Toxic. Lett. 17, 315 (1983).

11. J. M. Chemnitius, K. H. Haselmeyer and R. Zech, Life Sci. 34, 1119 (1984).

12. J. M. Chemnitius and R. Zech, Int. J. Biochem. 16, 361 (1984)

13. L. M. Hjelmeland and A. Chrambach, Meth. Enzym. 104, 305 (1984).

14. C. S. Davis, M. L. Barth, B. R. Dudek and R. J. Richardson, in Mechanisms of Toxicity and Hazard Evaluation (Eds. B. Holmstedt, R. Lauwerys, M. Mercier and M. Roberfroid), p. 63. Elsevier/North-Holland Biomedical Press, Amsterdam (1980).

15. M. L. Barth and R. J. Richardson, Development of an In Vitro Neurotoxicity Assay, USEPA Report EPA600/1-81-043 (PB81-208159). National Technical Information Service, Springfield (1981).

16. M. K. Johnson and J. M. Barnes, Biochem. Pharmac. 19, 3045 (1970)

17. M. K. Johnson, CRC Crit. Rev. Toxic. 3, 289 (1975).

18. B. R. Dudek, Ph.D. Thesis, The University of Michigan, p. 95. University Microfilms International, Ann Arbor (1979)

19. M. K. Johnson, Archs Toxic. 37, 113 (1977).

20. O. H. Lowry, N. J. Rosebrough, A. L. Farr and R. J. Randall, J. biol. Chem. 193, 265 (1951).

21. B. R. Dudek and R. J. Richardson, Biochem. Pharmac. 31, 1117 (1982).

22. R. R. Sokal and F. J. Rohlf, Biometry, 2nd Edn, p. 454. W. H. Freeman, New York (1981).

23. W. N. Aldridge, Biochem. J. 46, 451 (1950).

24. A. Helenius and K. Simons, Biochim biophys. Acta 415, 29 (1975).

25. R. D. Klausner, J. van Renswoude, R. Blumenthal and B. Rivnay, in Receptor Biochemistry and Methodology (Eds. J. C. Venter and L. C. Harrison), Vol. 3, p. 209. Alan R. Liss, New York (1984).

26. A. Helenius, D. R. McCaslin, E. Fries and C. Tanford, Meth. Enzym. 56, 734 (1979).

27. W. J. De Grip and P. H. M. Bovee-Geurts, Chem. Phys. Lipids 23, 321 (1979).

28. A. Davis, in Receptor Biochemistry and Methodology (Eds. J. C. Venter and L. C. Harrison), Vol. 3, p. 161. Alan R. Liss, New York (1984).

29. R. Coleman, Biochim. biophys. Acta 300, 1 (1973)

30. W. S. Agnew and M. A. Raffery, Biochemistry 18. 1912 (1979).

31. J. R. Brotherus, P. C. Jost, O. H. Griffith and L. E Hokin, Biochemistry 18, 5043 (1979). 